Ks. Tomasz STĘPIEN'*

\title{
WIARA SZUKAJĄCA ZROZUMIENIA W ASPEKCIE PRAKTYKI DĄŻENIA KU SZCZEĆSCIU W UJĘCIU PLATONA, PLOTYNA I ŚW. AUGUSTYNA
}

Zagadnienie wzajemnych relacji wiary i rozumu jest niewątpliwie jedną z ciekawszych kwestii, które są podejmowane w rozważaniach nad nauką Ojców Kościoła. $Z$ jednej strony są oni w tej materii podstawowym punktem odniesienia, ponieważ to właśnie ich teksty dostarczyły modelowego wzorca używania filozoficznych rozważań, jako narzędzia w budowaniu chrześcijańskiej teologii. Z drugiej strony formułuje się tu zarzut, że tak naprawdę nie możemy mówić w przypadku pisarzy patrystycznych o filozofii, ponieważ to, co budują jest w istocie teologią, skoro początkiem rozważań jest przyjęcie objawionej prawdy.

Celem niniejszego artykułu jest po pierwsze pokazanie, że samo stwierdzenie, iż wiara jest wcześniejsza od rozumu, nie stanowi jeszcze wystarczającego kryterium, aby odróżnić filozofię od teologii, ponieważ wiara w starożytnej filozofii bywa także przedstawiana jako koniecznie poprzedzająca poznanie rozumowe. Po drugie chciałbym także pokazać, że stawianie wiary przed rozumem nie jest dla starożytnych autorów kwestią teoretyczną, ale ma sens tylko w aspekcie kolejnych etapów życia filozoficznego. Aby to osiągnąć należy prześledzić zagadnienie wiary w pismach starożytnych filozofów. Ewolucję poglądów w tej kwestii najlepiej ukarze zestawienie twierdzeń Platona (428/427 - 348/347 prz. Chr.) i Plotyna (ok. 205-270), którzy właśnie ukazują filozofię jako drogę ku szczęściu. Podjęcie tej drogi łączy się zawsze z uznaniem autorytetu przewodnika, nauczyciela i filozofa, który na tę drogę wprowadza. Praktyka życia filozoficznego może się zacząć dopiero wtedy, kiedy uzna się prawdziwość słów nauczyciela, a zatem potrzebne jest tutaj także pewne zaufanie czy wiara, że istnieje możliwość dotarcia do szczęścia.

Dopiero na tym tle będziemy mogliprześledzić w jaki sposób ten filozoficzny model został zaadoptowany przez autorów chrześcijańskich. Z racji ograniczeń niniejszego artykułu do tego celu została wybrana postać św. Augustyna (354430), przede wszystkim dlatego, że jest on uważany za „Nauczyciela Zachodu”

* Ks. dr hab. Tomasz Stępień, prof. UKSW - kierownik Katedry Filozofii Religii w Instytucie Dialogu Kultury i Religii na Wydziale Teologicznym Uniwersytetu Kard. Stefana Wyszyńskiego w Warszawie; e-mail: t.stepien@uksw.edu.pl. 
także w kwestii wzajemnych zależności rozumu i wiary. Jego słynne credo ut intelligam, tak często powtarzane w filozofii średniowiecznej, bywa obecnie zazwyczaj rozumiane jako postawienie Objawienia przed poznaniem rozumowym. Nawet jeżeli przyznamy, że św. Augustyn faktycznie tak uważał, to i tak samo owo stwierdzenie jeszcze nie może świadczyć o pierwszeństwie wiary nadprzyrodzonej. Problem w przypadku św. Augustyna jest szczególnie jasno widoczny. Bardzo często bowiem w interpretacjach jego doktryny obserwujemy czynienie tego przez pryzmat współczesnego i całkowicie teoretycznego rozróżnienia sfer wiary i rozumu ${ }^{1}$.

1. Wiara i alegoria jaskini. Choć $w$ wielu swoich dialogach Platon zastanawia się nad prawdziwą naturą wiedzy, to jednak najbardziej kompletny wykład możemy zobaczyć w słynnej alegorii jaskini rozpoczynającej VII księgę $P a n ́ s t w a^{2}$. Cała metafora jest wyjaśnieniem tego, jak człowiek przechodzi przez poszczególne stany wiedzy, aby w końcu dojść do oglądania idei, które daje prawdziwą wiedzę. Już pod koniec VI księgi rozmówcy ustalają istnienie czterech stanów wiedzy w następujących słowach konkludujących wcześniejsze rozważania o naturze figur geometrycznych:

„I przyjmij wraz ze mną w związku z tymi czterema odcinkami następujące

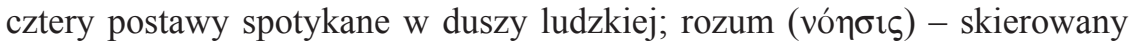
ku temu, co najwyższe, rozsądek ( $\left.\delta i^{\prime} v o l \alpha\right)$ - do tego, co drugie z kolei, trzeciemu rzędowi przyporządkuj wiarę ( $\pi i ́ \sigma \tau \imath \varsigma$ ), a temu co na końcu myślenie obrazami (cik $\left.\alpha \sigma^{\prime} \alpha\right)$ ). I uporządkuj to podobnie jak tamte rzeczy; im więcej

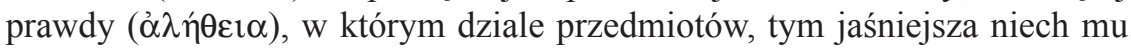
u ciebie odpowiada postawa wewnętrzna"’.

W tym miejscu Platon wyjaśnia stopnie poznania w odwrotnej kolejności. Najwyższy stopień to poznanie intelektualne (vónoıs), którego przedmiotem

${ }^{1}$ Kwestia ta jest oczywiście bardzo skomplikowana i niewątpliwie wygląda nieco odmiennie w zależności od autora interpretującego doktrynę św. Augustyna. Podkreśla się tutaj, że św. Augustyn nie odróżniał wiary i rozumu w sensie współczesnym, por. E. Gilson, Wprowadzenie do nauki św. Augustyna, tłum. Z. Jakimiak, Warszawa 1953, 38; R. Heinzmann, Filozofia średniowiecza, tłum. P. Domański, Kęty 1999, 60n. Wydaje mi się jednak, że możemy tutaj zobaczyć pewną wspólną cechę jednoznacznego pojmowania wiary jako postawy czysto religijnej. Taka postawa sprawia, że Biskupa Hippony należy traktować jako teologa, z którego rozważań możemy jedynie wyłuskiwać filozoficzne wątki, zob. np. Heinzmann, Filozofia średniowiecza, s. 60n; F. Copleston, Historia filozofii, thum. S. Zalewski, t. 2, Warszawa 2004, 48-50; S. Swierzawski, Dzieje europejskiej filozofii klasycznej, Warszawa - Wrocław 2000, 339-344. Wielce sugestywna jest w tej materii uwaga E. Gilsona (Wprowadzenie, s. 38), który pisząc o jedności filozofii i religii u św. Augustyna stwierdza: „Czysta historia filozofii nie może iść dalej. Filozof może żałować, że Augustyn nie postawił zagadnienia inaczej, ale tak właśnie je postawił. Filozofia, która chce być prawdziwą przyjaciółką mądrości, powinna wychodzić z wiary, której będzie zrozumieniem".

${ }^{2}$ Por. Plato, Respublica VII 1-2, 514A - 516C, ed. E. Chambry, w: Platon, Oeuvres Complètes, t. VII/1, Paris 1933, 144-148, tłum. W. Witwicki: Platon, Państwo. Prawa, Kęty 1999, 220-223.

${ }^{3}$ Tamże VI 21, 511D-E, ed. Chambry, s. 142-143, thum. Witwicki, s. 219. 
są idee. Niższy stopień poznania to rozsądek, czy też, poznanie pośrednie ( $\delta i \alpha ́ v o r \alpha)$, dotyczące przedmiotów matematycznych. Trzeci stopień to właśnie wiara $(\pi i \sigma \tau \imath \varsigma)$, która jest wyższą formą poznania przedmiotów zmysłowych, a ostatni to wyobrażenie ( $\left.\varepsilon^{i \kappa \alpha} \alpha \dot{i} \alpha\right)$ tak samo dotyczące tego, co zmysłowe. Wcześniej Platon zaliczył dwa pierwsze rodzaje poznania odnoszące się do przedmiotów intelektualnych do wiedzy $(\dot{\varepsilon} \pi \imath \sigma \tau \eta \dot{\eta} \mu)$ natomiast w przypadku dwóch kolejnych określił je mianem mniemania $(\delta o ́ \xi \alpha)^{4}$.

Powyższy podział pokazuje więc, że wiara jest dla Platona pewnym rodzajem poznania rzeczy zmysłowych. Trzeba jednak zaznaczyć, że nie chodzi tutaj o wiarę w rozumieniu religijnym, ale o pewne prawdziwe przekonanie, które człowiek ma na temat zmysłowych przedmiotów, nie poznanych jeszcze w sposób doskonalszy. Wiara jest jednak wyższa od zwykłego wyobrażenia, ponieważ wyższa jest pewność wiary. Dlatego właśnie możemy uważać, że jest ona tożsama z tym, co Platon nazywa słusznym mniemaniem (ỏp $\theta \grave{\eta}$ $\delta o ́ \xi \alpha)$. Różni się ona od wiedzy tym, że w przypadku wiedzy prawdziwe sądy o rzeczach są ze sobą powiązane wewnętrzną logiką wynikającą z poznania przyczyn ( $\alpha i \tau^{\prime} \alpha \varsigma \lambda$ o $\left.\gamma i \sigma \mu \hat{\omega}\right)^{5}$. Zatem jako niedoskonała postać wiedzy ma ona w sobie niższy stopień prawdy niż poznanie intelektualne.

Niezwykle ważny dla naszych rozważań jest kontekst, w którym Platon mówi o wierze. Jest ona przedstawiana w wyjaśnieniu alegorii jaskini, jako pewien etap poznania, który jest konieczny, aby dojść do wiedzy. Przypomnijmy, że alegoria ta przedstawia ludzi, którzy zostali przykuci w jaskini w taki sposób, że mogą ogląać tylko cienie rzeczy zmysłowych. Platon opowiada o tym, że droga prawdziwego filozofa polega na wyzwoleniu się z tych kajdan, aby móc wyjść z jaskini i oglądać nie tylko cienie rzeczy zmysłowych, ale coś jeszcze większego, czyli idee, które są oświetlane prawdziwym słońcem najwyższej idei Dobra. Aby tego dokonać człowiek musi nie tylko wyzwolić się z samych kajdan, ale wyjść z jaskini ku światłu, które daje prawdziwą wiedzę o rzeczach. Zatem Platonowi nie chodzi tutaj jedynie o przedstawienie rodzajów poznania, ale o pokazanie drogi, przy pomocy której człowiek będzie mógł dostapić prawdziwego poznania idei. Ponieważ zaś cała rozmowa $\mathrm{i}$ alegoria przedstawiane są $\mathrm{w}$ dialogu dotyczącym idealnego państwa, jeszcze bardziej szczegółowym kontekstem jest pytanie w jaki sposób można wychowywać przyszłych władców państwa, czyli prawdziwych filozofów.

${ }^{4}$ Tamże V 20, 476E - 477B, ed. Chambry, s. 93-94, thum. Witwicki, s. 181-182. Na temat podziału rodzajów poznania u Platona por. także: G. Reale, Historia filozofii starożytnej, tłum. E.I. Zieliński, t. 2, Lublin 1996, 198-201.

${ }^{5}$ Widać to dobrze we fragmencie Menona, w którym Platon wyjaśnia, że nie sama wiedza

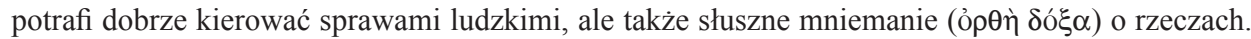
Słuszne mniemanie jednak nie pozwala na utrzymanie sądów w duszy człowieka i dlatego „związ-

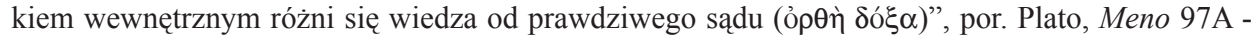
98B, ed. A. Croiset, w: Platon, Oeuvres Complètes, t. III/2, Gorgias - Menon, Paris 1965, 274-276, thum. W. Witwicki, w: Platon, Dialogi, t. 1, Kęty 1999, 497-499). 
Platon doskonale zdaje sobie sprawę z tego, że człowiek, który całe życie oglądał cienie rzeczy w jaskini, nie jest w stanie od razu widzieć światła. Cztery etapy poznania są więc kolejnymi stadiami, jakie musi przejść człowiek. Nie jest to więc obraz statyczny, czy suche rozróżnianie, ale opis dynamicznego przejścia, przez które nauczyciel musi przeprowadzić swojego ucznia. Natura wiary odsłania się zatem w konfrontacji z sąsiadującymi z nią poziomami wiedzy: wyobrażeniem i poznaniem pośrednim.

Mówiąc o wyobraźni Platon twierdzi, że jej przedmiotem są cienie, które zmysłowe rzeczy rzucają na ścianę jaskini dzięki sztucznemu źródłu światła (ogień). Jak zauważa Gail Fine, poznanie poprzez wyobrażenia w Państwie polega nie tylko na tym, że niewolnicy widzą jedynie przedmioty, ale raczej na tym, że nie potrafią oni rozpoznać różnicy pomiędzy cieniami a przedmiotami, które rzucają cienie. Nie potrafią zobaczyć, że cienie są mniej realne niż przedmioty, które je spowodowały. Ten brak rozróżnienia ma więc bardziej filozoficzną naturę, ponieważ polega na niemożliwości systematycznego rozróżnienia przyczyny i skutku (przedmiotu i cienia). Dlatego też filozof, który w dalszej części alegorii wraca do jaskini, aby powiedzieć niewolnikom o lepszym świecie, sam nie wraca do poprzedniego stanu, ponieważ potrafi systematycznie rozróżniać przyczyny i skutki ${ }^{6}$. Trzeba także zauważyć, że trwanie w wyobrażeniach może dotyczyć wielu płaszczyzn. Nie chodzi tutaj tylko o samo poznanie rzeczy jako takich, ale także o poznanie moralne. Równie ciężko, a może nawet trudniej, jest ujrzeć prawdziwe dobro moralne i dlatego ci, którzy są zanurzeni w wyobrażeniach ,walki staczają o cienie i o władzę, jak gdyby władza była jakimś wielkim dobrem"7.

Przejście od wyobrażeń do wiary może dokonać się dopiero wtedy, gdyby „ktoś został wyzwolony i musiałby zaraz wstać i obrócić szyję i iść i patrzeć na światło" . Jednak niewolnik musi przejść stopniowy proces uczenia się jak rozróżniać przedmiot i cień. Nie dzieje się to w sposób łagodny, ponieważ wcześniej dla niego cienie były całą rzeczywistością, którą znał. W tym miejscu istotna jest rola nauczyciela. Platon nie pisze bowiem, że to sam człowiek uczy się owych rozróżnień, tylko jest on w tym momencie przez kogoś pytany. Co więcej wyzwolony niewolnik jest tak niechętny doskonalszemu poznaniu, że musi być „zmuszany pytaniami”, aby powiedział, co naprawdę widzi ${ }^{9}$. Komentując ten fragment G. Fine zauważa podobieństwo do innych dialogów Platona, w których Sokrates (470/469 - 399 prz. Chr.) spotyka się z rozmówcami podobnie wierzącymi, że znają naturę jakiejś rzeczy. Dopiero

\footnotetext{
${ }^{6}$ Por. G. Fine, Knowledge and Belief in Republic V-VII, w: Plato. 1, Metaphysics and Epistemology, ed. G. Fine, Oxford 1999, 232.

${ }^{7}$ Plato, Respublica VII 5, 520C-D, ed. Chambry, s. 154, thum. Witwicki, s. 227.

${ }^{8}$ Tamże VII 1, 515C, ed. Chambry, 146, thum. W. Witwicki, 222.

${ }^{9}$ Por. tamże VII 1, 515E, ed. Chambry, s. 147, thum. Witwicki, s. 222. Owo zadawanie pytań jest niższą postacią dialektyki, która jest przedstawiana w dalszej części dialogu jako metoda doprowadzania człowieka do oglądania idei.
} 
kłopotliwe pytania Sokratesa podważające tę wiarę zmuszają ich do ponownej odpowiedzi na pytanie: „Czym ta rzecz jest?”. W wielu wczesnych dialogach (np. Eutyfron) cała rozmowa kończy się w tym momencie bez udzielenia zadowalającej odpowiedzi. Wpływ nauczyciela jest więc negatywny, albo przynajmniej jest on w stanie uświadomić rozmówcy jego niewiedzę. W alegorii jaskini jednak frustracja byłego niewolnika może zostać przezwyciężona, a on sam doprowadzony do wyższego stadium poznania jakim jest wiara ${ }^{10}$.

Stan poznania wyższy od wiary jest możliwy do osiagnięcia dopiero wtedy, kiedy człowiek zostanie wyprowadzony z jaskini. Choć w tekście przedstawiającym alegorię jaskini nie znajdziemy jasnego rozróżnienia poznania po-

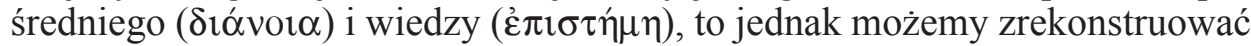
typ poznania pośredniego na podstawie tego, co wcześniej pisał o poznaniu przedmiotów geometrii. $\Delta$ cóvoı $\alpha$ jest tutaj przedstawiana właśnie jako wiedza o przedmiotach matematyki. Matematyka według Platona zajmuje się głównie dowodzeniem, ale nie prowadzi ono samo w sobie do pełnej wiedzy, polegającej na bezpośrednim widzeniu przyczyn - idei. I choć rysują oni figury geometryczne to czyniąc to tak naprawdę nie myślą o figurach, które narysowali, ale raczej o wiecznych ideach ${ }^{11}$. Innymi słowy to, co geometra narysował jest tylko cieniem i zmysłowym obrazem tego, czym jest ono w istocie, czyli idei, pozostającej w swej naturze całkowicie poza światem materialnym. Platon w tym miejscu zdaje się sugerować, że sytuacja matematyka jest w pewnym stopniu podobna do sytuacji niewolnika. Tak jak niewolnik nie potrafi się oderwać od rzeczy zmysłowych, podobnie matematyk zatrzymuje się jedynie na zmysłowych obrazach prawdziwych idealnych przedmiotów matematyki. Zajmując się matematyką człowiek musi się posługiwać pewnymi założeniami (író $\theta \varepsilon \sigma ı)$ :

„kiedy je badać zechce, i nie do szczytu i początku wtedy zmierza, bo nie potrafi wyjść z tego, w czym tkwi i wznieść się ponad założenia; jako obrazów dusza używa wtedy tych przedmiotów, które się odwzorowują w jeszcze niższych, bierze je za rzeczy same i ceni je jako naoczne i wyraźne"12.

W przypadku zatem niższego poznania intelektualnego mamy do czynienia znowu z pewnego rodzaju kajdanami duszy. Przy czym przejście z poznania pośredniego do prawdziwej wiedzy dokonuje się znowu dzięki żmudnemu procesowi dialektycznemu. Dopiero wtedy człowiek może dojść do prawdziwego rozumienia rzeczy (vónoıs), kiedy widzi idee. Możemy więc zrozumieć, dlaczego Platon w dalszej części Państwa zestawia z sobą rodzaje poznania

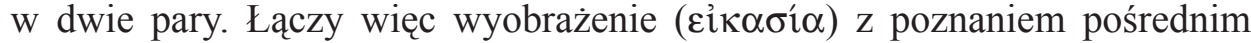

${ }^{10}$ Por. Fine, Knowledge and Belief, s. 234. Autor zauważa tutaj także podobieństwo do platońskiego Menona (98A), w którym niewolnik w podobny sposób jest prowadzony do wyższej postaci wiedzy dotyczącej geometrii.

${ }^{11}$ Por. Plato, Respublica VI 20, 510C-D, ed. Chambry, s. 141, thum. Witwicki, s. 217.

${ }^{12}$ Tamże VI 21, 511A, ed. Chambry, s. 141, thum. Witwicki, s. 217-218. 


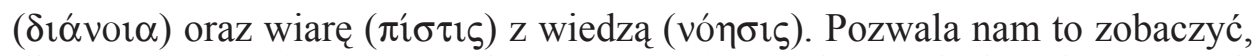
dlaczego wiara jest przez Platona rozumiana jako najdoskonalszy sposób poznania zmysłowego. Jest tak, ponieważ podobnie jak prawdziwa wiedza w sferze intelektualnej, ona w tym co zmysłowe jest skierowana nie na cień przedmiotu, ale na sam przedmiot.

Nie trzeba chyba nikogo przekonywać o tym jak ważna jest alegoria jaskini. Do dziś pozostaje ona jednym z najbardziej znanych tekstów Platona. Podobnie zresztą było w świecie starożytnym, a już szczególnie w całym nurcie platońskim. Niezwykle istotne jest również przedstawienie wiary jako pewnego etapu, który jest konieczny na drodze do prawdziwej wiedzy. A jest ona etapem niezwykle istotnym, ponieważ tylko dzięki zwróceniu uwagi na to, czym jest przedmiot zmysłowy, można w człowieku obudzić pragnienie pełnej wiedzy o tym, co ponadzmysłowe. Można także powiedzieć, że już u Platona (choć jeszcze nie jest to jasno wyrażone) wiara prowadzi do prawdziwego rozumienia rzeczy. Choć mogłoby się wydawać, że jest tak jedynie w aspekcie czysto poznawczym, to jednak w myśli platońskiej nie sposób oddzielić poznania od pierwiastka religijno-mistycznego. Stanie się to szczególnie jasne, kiedy jego dialogi zostaną zinterpretowane na nowo, najpierw przez Plotyna w III w. po Chr., a następnie przez kolejnych neoplatoników, co dokona się już $\mathrm{z}$ wyraźnie mistycznej perspektywy ${ }^{13}$. Z pewnością w kluczu dążenia duszy do zjednoczenia z tym, co boskie, możemy także interpretować alegorię jaskini ${ }^{14}$.

\section{Wiara konieczna w dążeniu do Jednego i oglądaniu Jednego.} W pierwszej enneadzie Plotyn poświęca sporo miejsca dialektyce, jako umie-

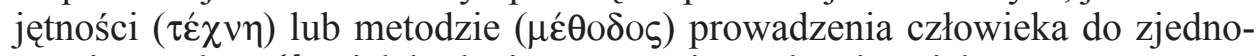
czenia z Jednym ${ }^{15}$. Dialektyka jest przez niego określana jako

„Zdolność pojęciowego i słownego określania każdej rzeczy, a mianowicie: czym jest rzecz każda, czym się różni od innych i na czym polega wspólnota"”.

Powtarza się tutaj sytuacja z platońskiej alegorii jaskini, ponieważ Plotyn nie pisze o człowieku, który sam postępuje w górę, ale mówi o prowadzeniu go. Do takiego prowadzenia nadają się trzy rodzaje ludzi: filozof, muzyk i miłośnik (kochający). Plotyn zajmuje się najpierw muzykiem i pokazuje jak od harmonii słyszalnych dźwięków można go prowadzić do tego, co niewidzialne - do

${ }^{13}$ Por. Reale, Historia filozofii, t. 2, s. 217: „Starożytni dostrzegli, że filozofia Platona była do głębi przeniknięta duchem religijnym, który był niewyczerpanym źródłem dla duchów spragnionych tego, co boskie. Niektórzy uznali ją wręcz za wtajemniczenie mistyczne: wielu neoplatoników zaczęło traktować dialogi platońskie jako odpowiedzi wyroczni, jako boskie objawienie". Autor przywołuje na poparcie tych słów wielce sugestywny fragment z Teologii platońskiej Proklosa (412-485).

${ }^{14}$ Por. A. Louth, Poczatki mistyki chrześcijańskiej, tłum. H. Bednarek, Kraków 1997, 17-22.

${ }^{15}$ Plotinus, Enneades I 3, 1, ed. P. Henry - H.R. Schwyzer, w: Plotinus, Opera, t. 1, Paris - Bruxelles 1951, 73, thum. A. Krokiewicz: Plotyn, Enneady I-III, Warszawa 2000, 107).

${ }^{16}$ Tamże I 3, 4, ed. Henry - Schwyzer, t. 1, s. 76, thum. Krokiewicz, s. 109. 
harmonii intelektualnej, która jest zasadą harmonii zmysłowej. Proces kończy się ostatnim etapem, w którym ,należy mu wreszcie podać świetlane orędzia filozofii i stąd doprowadzić go do wiary $(\pi i \sigma \tau \iota \varsigma)$ w te skarby, które posiada, i o których nie wie, że je posiada"17. Zatem w tym fragmencie wiara nie jest już tylko etapem, który należy przejść, aby dojść do oglądania prawdziwej rzeczywistości, ale jest ona potrzebna nawet dla ludzi, którzy już wznieśli się do intelektualnego świata. W tym wyższym etapie dialektyki konieczne jest także przekonanie (wiara), że człowiek posiada w sobie idee, które może zobaczyć.

Z kolei w piątej enneadzie Plotyn zajmując się jednością intelektu (vov̂s),

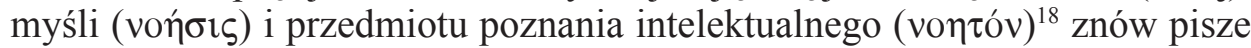
o konieczności wiary. Jest to bardzo ważny moment, ponieważ dopiero dzięki nabyciu przekonania, że te rzeczy są jednością może zacząć się przejście duszy z poziomu intelektu do oglądania najwyższego Jednego. Nie może się to

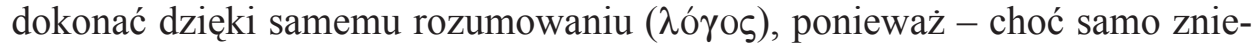
wala ono swoją oczywistością - to nie wystarczy do przekonania duszy, że podzielone rzeczy w świecie intelektualnym tak naprawdę stanowią jedność.

„Czy więc takie jest to, co wykazał wywód ( $\lambda$ ó

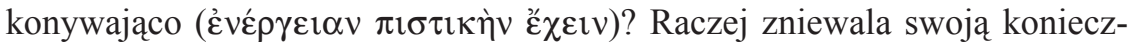
nością, a nie przemawia do przekonania. Jakoż konieczność jest w umyśle,

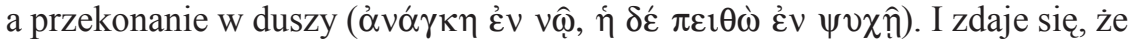
nam bodaj więcej na tym zależy, żebyśmy byli przekonani, niż żeby czystym umysłem oglądać prawdę"19.

Do tego, aby dusza postępowała naprzód, nie wystarczy zatem sama pewność płynąca z rozumowania. Jak widzieliśmy u Platona, tym właśnie różniła się wiara od wiedzy, że wierze brakowało wewnętrznego uzasadnienia i logiki. Wiara więc stawała się niepotrzebna, kiedy wkraczała rozumowa pewność. Tymczasem Plotyn zauważa, że nawet kiedy nasz intelekt pozna już wewnętrzną konieczność płynącą z rozumowań, a nawet $\mathrm{z}$ widzenia tego, co intelektualne, to ciągle nie jest to wystarczające aby iść naprzód. Potrzebny jest pozaintelektualny element wolitywny, który daje przekonanie, że ponad światem intelektu jest jeszcze samo Jedno. Wiara rozumiana jako wewnętrzne przekonanie duszy jest więc $\mathrm{w}$ dalszym ciągu potrzebna i konieczna. Możemy nawet uważać, że według Plotyna tylko tak rozumiana wiara może zapewnić człowiekowi przekroczenie tego, co czysto rozumowe. Człowiek więc „wierząc niezłomnie ( $\mu \alpha \theta$ óv $\tau \alpha \kappa \alpha \tau \grave{\alpha}$ $\pi i \sigma \tau \imath v)$, że wchodzi w arcyszczęsną rzeczywistość, musi całym sobą rzucić się do wnętrza i stać się zamiast widza widzeniem widza widzianego, który „stamtąd" przybywa, i musi rozbłysnąć takimi, jak on, myślami"20.

${ }^{17}$ Tamże I 3, 1, ed. Henry - Schwyzer, t. 1, s. 74, tłum. Krokiewicz, 108.

${ }^{18}$ Tamże V 3, 5, ed. Henry - Schwyzer, w: Plotinus, Opera, t. 2, Paris - Bruxelles 1953, $304-$ 305, thum. Krokiewicz: Plotyn, Enneady IV-V, Warszawa 2000, 526-527.

${ }^{19}$ Tamże V 3, 6, ed. Henry - Schwyzer, t. 2, s. 306, tłum. Krokiewicz, s. 527.

${ }^{20}$ Tamże V 8, 11, ed. Henry - Schwyzer, t. 2, s. 402n, thum. Krokiewicz, s. 581. 
W jeszcze innym fragmencie piątej enneady Plotyn bardzo mocno podkreśla wewnętrzny charakter przedmiotów intelektualnych i to, że dusza musi odkryć je w sobie, przy okazji wyjaśniając także, jaka jest różnica pomiędzy pewnością (wiarą), a koniecznością płynącą z rozumowania. Okazuje się, że dowód może być przedstawiony przez nauczyciela i dany z zewnątrz, gdy tymczasem prawdziwa wiedza musi być odkryciem czegoś w głębi duszy ${ }^{21}$. Rozumowanie jednak, choć samo nie wystarcza, jest konieczne jako etap w drodze. Tylko ten, któremu zostało dane rozumowanie i który przekonał się o istnieniu Jednego, może uważać, że zjednoczenie z nim jest w ogóle możliwe. Dlatego Plotyn w szóstej enneadzie, zachęcając do przekroczenia etapu intelektu i przejścia jeszcze głębiej do ,wewnątrz”, pisze:

„Więc jeśli ktoś tam jeszcze nie jest, lecz z wymienionych wyżej powodów pozostaje na zewnątrz albo też dlatego, że brak mu rozumowania, które po-

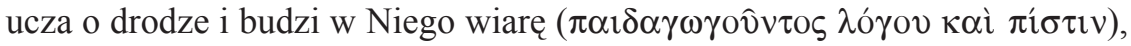
to $\mathrm{w}$ razie tamtych powodów niech sam siebie wini i próbuje, porzuciwszy wszystko, być tylko sobą [...]"22.

W podobny sposób Plotyn wyraża się nie tylko o dochodzeniu do ponadintelektualnej rzeczywistości, ale także o samym oglądaniu ( $\theta \varepsilon \omega \rho i ́ \alpha)$ Jednego, które nie znajduje się na zewnątrz, ale w duszy oglądającego ${ }^{23}$. Wiara pełni tutaj także bardzo istotną rolę. Plotyn pisze:

„Albowiem wtedy dusza pozostaje w spokoju i nie szuka niczego, jako że jest nasycona, a także «oglądanie» wobec takiej pewności $(\pi i ́ \tau \tau \iota \varsigma)$ posiadania spoczywa wewnątrz. I im owa pewność ( $\pi i \sigma \tau \imath \varsigma$ ) jaśniejsza, tym cichsze jest także «oglądanie» jako że bardziej «jednoczy», i to, co poznaje, zdąża w miarę poznawanie - czas już bowiem rzec słowo poważne - do jedności z tym, co zostało poznane" 24 .

Okazuje się więc, że nawet w oglądaniu Jednego wiara, jest konieczna. Jest ona rozumiana jako przekonanie o posiadaniu tego, co się ogląda. Ważne jest również, że Plotyn pisze, iż jakość oglądu Jednego zależy od stopnia wiary -

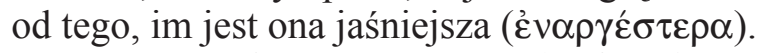

Powyższe fragmenty Ennead pokazują wyraźnie, że u Plotyna następuje bardzo istotna przemiana interpretacyjna roli wiary we wstępowaniu duszy do Boga. Wiara nie jest już typem poznania zmysłowego, ale staje się przekonaniem, które towarzyszy człowiekowi na każdym etapie jego drogi. Taki

${ }^{21}$ Por. tamże V 5, 1, ed. Henry - Schwyzer, t. 2, s. 340-341, tłum. Krokiewicz, s. 546: „Musi tedy jako taki wiedzieć zawsze i nigdy nie zapominać, a ta wiedza jego ani na przypuszczeniach polegać nie może, ani też być wątpliwa i z drugiej znowu strony nie może mu tak przysługiwać, jakby ją «posłyszał» skądinąd, a więc także nie dzięki dowodowi”.

${ }^{22}$ Tamże VI 9, 4, ed. F. Dubner, Paris 1855, 532, thum. Krokiewicz: Plotyn, Enneady VI, Warszawa 2000, 830 .

${ }^{23}$ Por. tamże III 8, 6, ed. Henry - Schwyzer, t. 1, s. 401-402, tłum. Krokiewicz, s. 352.

${ }^{24}$ Tamże III 8, 6, ed. Henry - Schwyzer, t. 1, s. 402-403, thum. Krokiewicz, s. 352-353. 
pogląd rysuje się przede wszystkim w kontekście wolitywnego aspektu wiary. Sam intelekt i nawet widzenie idei nie wystarczy. Jest to widoczne szczególnie jasno w najważniejszym momencie drogi człowieka do Jednego, która wiąże się z wykroczeniem poza to, co intelektualne. Sam fakt wyjścia poza sferę intelektu powoduje, że konieczny jest także pozarozumowy element, który w tym momencie da człowiekowi przekonanie, że jest na właściwej drodze.

\section{3. Św. Augustyn - wiara szukająca zrozumienia. W kontekście wcze-} śniejszych rozważań dotyczących Platona i Plotyna możemy przedstawić kilka uwag dotyczących relacji wiary i rozumu u św. Augustyna. W tym miejscu nie jesteśmy w stanie choćby zarysować tego zagadnienia, uważam jednak, że kontekst rozumienia wiary $u$ dwóch poprzednich autorów pozwoli na spojrzenie na poglądy św. Augustyna w nieco innym świetle. Zwłaszcza, że wpływ Plotyna na myśl biskupa Hippony pozostaje niewątpliwy. Istnieje jednak problem przejścia z narracji greckiej do łacińskiej. Greckie $\pi i \sigma \tau \imath \varsigma$ nie znaczy bowiem dokładnie tego samego, co łacińskie fides. Wielce pomocne byłoby w tej materii sięgnięcie do łacińskich tłumaczeń, z których korzystał św. Augustyn, ale niestety Libri platonicorum, na które się powołuje, nie zachowały się ${ }^{25}$. $\mathrm{Z}$ tej racji, choć wpływ jest niewatpliwy, to jednak w kwestiach rozumienia szczegółowych źródeł myśli neoplatońskiej musimy zadowolić się pewnymi przybliżeniami. Mimo to, jak zobaczymy, w tej materii nawiązania do autorów pogańskich są wyraźnie widoczne.

Trzeba także dokonać rozróżnień, które mają bardzo istotne znaczenie dla rozumienia samych tekstów. Po pierwsze, w dziełach św. Augustyna pojawia się inne, nie znane autorom pogańskim rozumienie wiary, która jest cnotą boską i łaską ${ }^{26}$. O ile więc wiara $\mathrm{w}$ tekstach filozoficznych będzie miała czysto naturalny wymiar, o tyle $u$ autorów chrześcijańskich (w tym szczególnie u św. Augustyna) pojawia się wiara jako niezasłużony dar od Boga, czyli łaska. Po drugie trzeba także i w przypadku św. Augustyna odróżnić rozum (ratio), jako władzę przeprowadzającą rozumowanie, od zrozumienia (intellectio), które jest już pojęciem prawdy uzyskanej w wyniku rozumowania. Jest to o tyle ważne, że nie jest tym samym zestawienie wiary z rozumem i wiary ze zrozumieniem.

Najprostsza definicja wiary, którą znajdujemy u biskupa Hippony, określa ją jako myślenie, któremu towarzyszy przyzwolenie (cum assensione cogita$r e)^{27}$. Wiara jest konieczna, ponieważ nie można myśleć o tym, czego się nie

${ }^{25}$ Por. Augustinus, Confessiones VII 9, 13, ed. M. Pellegrino, NBA 1, Roma 1965, 194; tamże VIII 2, 3, NBA 1, 219n.

${ }^{26} \mathrm{O}$ ile pojęcie cnót wyższych od cnót moralnych i intelektualnych, jako doskonałości koniecznych do osiagnięcia zjednoczenia z Jednym było neoplatonikom znane, to jednak w pogańskiej filozofii nie istniało pojęcie łaski, jako czegoś, co przekracza naturę, por. W.J. Hankey, Philosophy as way of life for Christians? Iamblichan and Porphyrian reflections on Religion, Virtue, an Philosophy in Thomas Aquinas, LThPh 59 (2003) nr 2, 193-224.

${ }^{27}$ Augustinus, De praedestinatione sanctorum II 5, ed. A. Trapè, NBA 20, Roma 1987, 299: „Quanquam et ipsum credere, nihil aliud est, quam cum assensione cogitare. Non enim omnis qui 
widziało inaczej, jak wierzac $w$ to uprzednio. $Z$ drugiej strony nie wszystko o czym się myśli jest przedmiotem wiary. Poznanie dzięki wierze tym różni się od rozumowania, że dzięki temu drugiemu człowiek sam jest w stanie zobaczyć prawdę, podczas gdy przyjmując coś bez możliwości zrozumienia musimy się oprzeć na autorytecie. Jeżeli więc słyszę człowieka, który wypowiada swoje myśli, to muszę mieć powód, aby uwierzyć jego słowu ${ }^{28}$. Jak to zaznacza Étienne Gilson (1884-1978), św. Augustyn zachęca w ten sposób do porzucenia ludzkiej pychy i przyjęcia tego, co wynika z Bożego autorytetu ${ }^{29}$. Jednak wcale nie musi to oznaczać, że taka kolejność nie zachodzi w przypadku naturalnego poznania, w którym także nie da się dojść do zrozumienia czegokolwiek, jeżeli wcześniej nie uwierzy się temu, co się słyszy. Choć oczywiście rozumienie rzeczy jest dużo doskonalszym widzeniem prawdy niż przyjmowanie jej na podstawie autorytetu, to w filozofii starożytnej przyjmowano także takie źródło poznania. Różnica opiera się na tym, co zewnętrzne i wewnętrzne. To, co oparte na autorytecie jest dane, natomiast to, co wynika $\mathrm{z}$ rozumowania jest uzyskane przez człowieka ${ }^{30}$. Jak to widzieliśmy, zwłaszcza w przypadku alegorii jaskini, wiara jest także poprzedzona niższym poznaniem zmysłowym. Przejście do poznania przez wiarę dokonuje się dzięki komuś, kto z zewnątrz do wiary doprowadza poprzez zadawanie dialektycznych pytań, aby później dopiero mógł dojść do rozumowych uzasadnień. Jak pamiętamy, Platon też zwracał uwagę na to, że istota wiary polega na odwróceniu się człowieka od cieni ku samym zmysłowym rzeczom. Jednak, aby to mogło nastapić, należy usłyszeć pytania, które zadaje nauczyciel. Autorytet nauczyciela jest więc zawsze przed rozpoczęciem rozumowania, które prowadzi do zrozumienia prawdy.

Św. Augustyn podejmuje i znacząco rozwija te wątki. Skoro autorytet nauczyciela jest tak ważny, aby móc uwierzyć i zwrócić się ku rzeczom, to podstawową kwestią pozostaje pytanie, kto taki autorytet posiada. Biskup Hippony odpowiada na to pytanie w ostatniej części dialogu $O$ nauczycielu, w którym zastanawia się on nad tym, czy człowiek może nauczyć się czegoś dzięki słowom. Okazuje się, że jedyną wartością słów jest to, że mogą jedynie pobudzić człowieka do szukania rzeczy (admonent tantum ut quaeramus res) ${ }^{31}$. Choć mogłoby się wydawać, że same słowa uczą człowieka, to jednak św. Augustyn pokazuje bardzo wyraźnie, że najpierw musimy znać rzecz, aby wiedzieć, że słowo tę rzecz oznacza. Słowo jest bowiem tylko umownym znakiem i aby je

cogitat, credit; cum ideo cogitent plerique, ne credant: sed cogitat omnis qui credit, et credendo cogitat, et cogitando credit".

${ }^{28}$ Por. tenże, Epistula 147 (ad Paulinum) 2, 7, ed. L. Carrozzi, NBA 22, Roma 1971, 374.

${ }^{29}$ Por. Gilson, Wprowadzenie, s. 34.

${ }^{30}$ Por. uwagi Arystotelesa na temat środków przekonywania w: Aristoteles, Rhetorica I 2, 1355b, ed. M. Dufour, t. 1, Paris 1932, 76, thum. H. Podbielski: Retoryka, Warszawa 1988, 67.

${ }^{31}$ Augustinus, De magistro XI 36, ed. A. Trapè - D. Gentili, NBA 3/2, Roma 1992, 782, thum. J. Modrzejewski: Augustyn, O nauczycielu, w: Dialogi filozoficzne, t. 3, Warszawa 1953, 61; tamże XIV 46, NBA 3/2, 792-794, thum. Modrzejewski, s. 69n. 
zrozumieć należy uprzednio poznać samą rzecz (res ipsa), którą możemy połączyć z tym, co ono oznacza ${ }^{32}$. Dlatego właśnie podstawowym ograniczeniem słów jest fakt, że choć mogą one pobudzić do szukania rzeczy, to jednak „nie pokazują nam ich w ten sposób, żebyśmy mogli je poznać (non exhibent ut noverimus)" "33. Skąd więc możemy czerpać wiedzę o rzeczach? Św. Augustyn wyjaśnia, że w przypadku rzeczy cielesnych możemy owe rzeczy zobaczyć. Jeżeli zobaczymy rzecz, to możemy dopasować do niej słowo. W przypadku przedmiotów intelektualnych także chodzi o podobne zobaczenie rzeczy, a słowa znów mogą nas jedynie skłonić do zwrócenia się ku nim. W tym miejscu jednak pojawia się zupełnie nowa postać nauczyciela, którym jest Chrystus mieszkający we wnętrzu człowieka, jako wewnętrzna Prawda. Tutaj także słowa mogą pobudzać nas do tego, abyśmy szukali w Chrystusie prawdy, ale są to już słowa wewnętrzne ${ }^{34}$. Choć mogło by się wydawać, że biskup Hippony przechodzi od tego, co naturalne, do tego, co nadprzyrodzone, to jednak odwołuje się on w tym miejscu do swojej doktryny o iluminacji, zgodnie z którą każdy człowiek otrzymuje treści intelektualne bezpośrednio od Chrystusa, który jest Logosem. Od iluminacji jest zależne poznanie nie tylko w wymiarze nadprzyrodzonym, ale każde poznanie intelektualne. Dlatego „każda rozumna dusza (omnis rationalis anima)" odwołuje się do Chrystusa w kwestii wewnętrznego widzenia prawdy. Jest On doskonałym i wewnętrznym nauczycielem także dlatego, że jednocześnie prowadzi człowieka do poznania i sam jest jego źródłem, ponieważ jest oświecającym Logosem. Pojawia się tutaj także znany nam już z rozważań Plotyna element wolitywny. Ludzie bowiem nie różnią się posiadanymi treściami intelektualnymi, ale raczej tym, na ile pozwala im ich szukać i je zobaczyć „dobra lub zła wola" 35 .

Św. Augustyn w ten sposób przeobraża platońską doktrynę poznania. $\mathrm{Z}$ jednej strony niewątpliwie nawiązuje do Plotyna, u którego także poznanie intelektualne duszy ludzkiej było możliwe dzięki ideom obecnym w drugiej hipostazie - Intelekcie (vôิs). Choć jednak, tak samo jak w przypadku Chrystusa, Intelekt jest hipostaza, a więc osobowym bytem, to jednak pouczanie duszy przez Chrystusa, który jest Logosem i pojmowanie Go jako wewnętrznego nauczyciela jest niewątpliwie akcentem chrześcijańskim. Zobaczmy, że jednocześnie $\mathrm{w}$ ten sposób następuje transformacja nauczyciela, który musiał udzielić swego pouczenia, aby człowiek mógł zwrócić się ku samym przedmiotom intelektualnym. W myśli pogańskiej był to zawsze filozof, który mógł

32 Tamże X 34, NBA 3/2, 780, tłum. Modrzejewski, s. 59-60.

${ }^{33}$ Tamże XI 36, NBA 3/2, 782, thum. Modrzejewski, s. 61.

${ }^{34}$ Por. tamże XI 38, NBA 3/2, 784: „De universis autem quae intelligimus non loquentem qui personat foris, sed intus ipsi menti praesidentem consulimus veritatem, verbis fortasse ut consulamus admoniti. Ille autem qui consulitur, docet, qui in interiore homine habitare dictus est Christus, id est incommutabilis Dei Virtus atque sempiterna Sapientia [...]", thum. Modrzejewski, s. 62-63.

${ }^{35}$ Por. tamże: ,[...] sed tantum cuique panditur, quantum capere propter propriam, sive malam sive bonam voluntatem potest. Et si quando fallitur, non fit vitio consultae veritatis, ut neque hujus, quae foris est, lucis vitium est". 
pobudzać duszę jedynie z zewnątrz. Choć Intelekt był także obecny w duszy człowieka, to jednak Plotyn nie uważa go za przewodnika duszy. Jak widzieliśmy kluczowy moment, w którym wiara była konieczna, to zwrócenie się ku Jednu i wejście do samego centrum wnętrza duszy, ponad to, co tylko intelektualne. W tej drodze jednak dusza była pozbawiona dobrego przewodnika. W omawianych wyżej fragmentach Ennead za takiego przewodnika zachęcającego duszę i prowadzącego w górę uważał się sam Plotyn ${ }^{36}$. U św. Augustyna rolę wewnętrznego przewodnika i nauczyciela przejmuje sam Chrystus. Jest On właśnie dlatego nauczycielem doskonałym, ponieważ jego działanie jest wewnętrzne, a więc całkowicie bezpośrednie i nie dokonujące się poprzez niedoskonałe znaki zmysłowe.

W tym fragmencie także św. Augustyn, przywołując przykład opowieści o trzech młodzieńcach z Ksiegi Daniela (3, 8-97), porusza zagadnienie wzajemnej relacji wiedzy i wiary. Biskup Hippony przyznaje, że raczej wierzy niż wie, że ta opowieść jest prawdziwa i że wiedzę i wiarę należy odróżniać:

„Dobrze zdawali sobie sprawę z tej różnicy sami owi święci autorzy, których słowom wierzymy. Mówi bowiem Prorok «Jeżeli nie uwierzycie, nie zrozumiecie»; na pewno nie powiedziałby tego, gdyby uważał, że żadna między tymi pojęciami nie zachodzi różnica. Jeżeli coś rozumiem, to i wierzę $w$ to, natomiast nie wszystko, w co wierzę - rozumiem. Wszystko zaś co rozumiem, to także wiem; nie wiem jednak wszystkiego, w co wierzę. Ale nie jest to powodem, żebym nie wiedział, jak pożyteczne jest wierzyć w wiele rzeczy, których nie wiem. W tym sensie uważam za pożyteczną także historię o trzech młodzieńcach; bo chociaż nie mogę wiedzieć wielu rzeczy, wiem jednak, z jak wielką korzyścią w nie wierzę" ${ }^{\text {"37 }}$.

Kluczem rozumienia tego tekstu są słowa, z księgi Izajasza $(7,9)$, które w wersji Wulgaty brzmią ,Jeżeli nie uwierzycie, nie ostoicie się (nisi credideritis, non permanebitis)". Wersja tekstu, z której korzystał św. Augustyn wydaje mu się bardzo ważna, ponieważ w niej wiara jest ukazana jako koniecznie poprzedzająca rozumienie (intelligentia). Zauważmy, że w powyższym fragmencie mamy do czynienia z trzema terminami: wierzyć (credo), wiedzieć (scire) i rozumieć (intelligere). Św. Augustyn stwierdza, że rozumienie zakłada wiedzę i wiarę. Nie sposób bowiem rozumieć jaką́ prawdę, ale

${ }^{36}$ Jest to widoczne zwłaszcza w omawianym wyżej fragmencie VI enneady, por. Plotinus, Enneades VI 9, 4-5, ed. Dubner, s. 532.

${ }^{37}$ Augustinus, De magistro XI 37, NBA 3/2, 784: „Haec autem omnia quae in illa leguntur historia, ita illo tempore facta esse, ut scripta sunt, credere me potius quam scire fateor: neque istam differentiam iidem ipsi quibus credimus nescierunt. Ait enim propheta [Is 7, 9 (sec. LXX)], Nisi credideritis, non intelligetis: quod non dixisset profecto, si nihil distare iudicasset. Quod ergo intellego, id etiam credo: at non omne quod credo, etiam intellego. Omne autem quod intellego, scio: non omne quod credo, scio. Nec ideo nescio quam sit utile credere etiam multa quae nescio; cui utilitati hanc quoque adiungo de tribus pueris historiam: quare pleraque rerum cum scire non possim, quanta tamen utilitate credantur scio", thum. Modrzejewski, s. 62-63. 
jednocześnie jej nie znać i nie być przekonanym o jej prawdziwości (nie wierzyć w jej prawdziwość). W tym przypadku daną rzecz za prawdziwą przyjmuje się na podstawie autorytetu samego rozumu, który jest w stanie ją przeniknąć i zbadać. Najpierw jednak trzeba ją zrozumieć, aby móc powiedzieć, że naprawdę posiadam o niej wiedzę. Prawdziwa wiedza bowiem, zgodnie z tym, co już twierdził o niej Platon, jest pewna. Taką pewność zaś można uzyskać tylko dzięki pełnemu rozumieniu jakiejś prawdy. Nie chodzi więc w tym miejscu o wiedzę w sensie posiadania jakichś informacji, ale raczej o pełną platońską غ̇ं

Wiara jednak wcale nie zakłada rozumienia i wiedzy. W samym przyjęciu jakiejś prawdy dzięki wierze nie jest jeszcze zawarte jej rozumienie. Dlatego właśnie trzeba przyznać, że mogę w coś wierzyć, ale jednocześnie nie posiadać ani zrozumienia ani wiedzy o tym, w co uwierzyłem. W ten sposób wiara jest zawsze przed intelektem i zrozumieniem - nisi credideritis, non intelligetis. Zauważmy jednak, że św. Augustyn nie zastanawia się tutaj nad tym, czy w ogóle da się zrozumieć to, w co się wierzy, czy prawdy te w ogóle są poznawalne. Niewątpliwe jest jednak dla niego, że wierząc w to, co mówi Pismo Święte może posiadać wiedzę (a więc całkowitą pewność) o tym, że prawdy te są dla niego pożyteczne ${ }^{38}$.

Trzeba także wskazać na jeszcze jedno rozróżnienie, które pada na końcu cytowanego fragmentu. Biskup Hippony twierdzi, iż niewiedza na temat tego, w co się wierzy wcale nie przeszkadza wiedzieć, że to, w co się wierzy jest pożyteczne. Tutaj podobnie nie musimy rozumieć owych słów w znaczeniu pożytków płynących z wiary nadprzyrodzonej. Równie dobrze można bowiem zdawać sobie sprawę z dobra, które płynie z używania jakiejkolwiek rzeczy, której działanie pozostaje dla nas tajemnicą. Innymi słowy nie muszę rozumieć zasady działania dźwigni, aby jej używać i wiedzieć, jak wiele mogę dzięki temu osiagnąć. Zatem także i w tym przypadku wiedza o tym, jak pożyteczna jest wiara w słowa Pisma Świętego, nie oznacza wcale, że dzieje się tak tylko w porządku nadprzyrodzonym.

Wróćmy jednak do sentencji nisi credideritis, non intelligetis, która jest przez św. Augustyna przywoływana w wielu miejscach ${ }^{39} \mathrm{i}$ jest to niewątpliwie jeden z jego ulubionych fragmentów Pisma Świętego. W bardzo wymownym fragmencie z De Trinitate, biskup Hippony odnosi tę sentencję bezpośrednio do szukania Boga. Przywołując liczne fragmenty Pisma Świętego, które mówią o tym, że należy stale, bez ustanku szukać Boga św. Augustyn dowodzi, że człowiek jednocześnie nieustannie znajduje Boga i zarazem znalazłszy Go ciągle dalej szuka. Podsumowując biskup Hippony pisze:

${ }^{38}$ Por. tamże: „Nec ideo nescio quam sit utile credere etiam multa quae nescio; cui utilitati hanc quoque adiungo de tribus pueris historiam: quare pleraque rerum cum scire non possim, quanta tamen utilitate credantur, scio".

${ }^{39} \mathrm{~W}$ sumie we wszystkich swoich dziełach św. Augustyn przytacza te słowa aż 38 razy. 
„Wiara szuka, rozum (intellectus) odkrywa. Dlatego Prorok powiada: «Jeśli wierzyć nie będziecie, nie zrozumiecie». I znowu rozum dalej szuka tego, co już znalazł, jak śpiewamy w Psalmie: «Pan z nieba spojrzał na synów człowieczych, aby zobaczyć, czy jest kto rozumny, albo szukający Boga». Po to więc człowiek ma rozum, żeby szukać Boga"40.

Niezwykle istotne jest, aby rozumieć ten fragment we właściwym kontekście, którym jest cel jaki stawia sobie autor na początku księgi piętnastej tego dzieła. Pisze on, że w pewnym sensie jest możliwe odnalezienie obrazu Trójcy Świętej w człowieku na drodze tylko rozumowej ${ }^{41}$. Zatem znowu, podobnie jak w przypadku poprzedniego fragmentu, możemy mówić o poznaniu na poziomie naturalnym. Sw. Augustyn uważa, że takie naturalne poznanie Boga jest możliwe, ale dostrzega również jego granice, ponieważ możliwości poznawcze rozumu są nikłe. Jednak fragment ten mówi wyraźnie, że wiara nie poprzedza rozumienia tylko raz, ale jest to raczej nieustanny proces, który ciągle się powtarza. Jest to bowiem naturalny sposób działania ludzkiego umysłu, który odkrywając coś zauważa, że jest przed nim ciagle jeszcze jakaś prawda, której nie poznał. Dlatego właśnie należy przyznać rację E. Gilsonowi, który uważa, że pierwszy skutek jaki wiara wywołuje w człowieku, to skierowanie się ku prawdzie. Jeżeli już się ku niej skieruje, to dopiero wtedy może zaczać się działanie rozumu, który zacznie prawdę odkrywać. Odkrywszy ją zaś będzie znów kierowany przez wiarę do poznawania coraz to nowych rzeczy ${ }^{42}$. W tym także sensie możemy rozumieć wiarę jako światło na poziomie naturalnym, ponieważ to właśnie ona $\mathrm{w}$ pewnym sensie odsłania i oświetla prawdę, którą intelekt dostrzega i której zrozumienia zaczyna poszukiwać.

Dzięki powyższym uwagom możemy także zrozumieć, że ten sam proces nieustannego odkrywania i poszukiwania może dokonywać się zarówno na poziomie przyrodzonym jak i nadprzyrodzonym. Tutaj także najpierw musi nastąpić wiara w słowa Pisma Świętego, w których oświetli ona prawdę. Wiara nadprzyrodzona także pobudzi intelekt do zwrócenia się ku prawdzie wiary i dlatego on znów zacznie poszukiwać zrozumienia. Zrozumienie zaś pobudzi wiarę, która z kolei przekona rozum o tym, że warto dalej prowadzić poszukiwania. Także do tego poziomu interakcji wiary i rozumu możemy spokojnie zastosować słowa św. Augustyna z XV księgi De Trinitate.

\footnotetext{
${ }^{40}$ Augustinus, De Trinitate XV 1, 2, ed. A. Trapè - M.F. Sciacca, NBA 4, Roma 1987, 618: „Fides quaerit, intellectus invenit: propter quod ait propheta, Nisi credideritis, non intelligetis. Et rursus intellectus eum quem invenit adhuc quaerit: Deus enim respexit super filios hominum, sicut in Psalmo sacro canitur, ut videret si est intelligens, aut requirens Deum. Ad hoc ergo debet homo esse intelligens, ut requirat Deum”, thum. M. Stokowska: Augustyn, O Trójcy Świętej, Kraków 1996, 460.

${ }^{41}$ Por. tamże XV 1, 1, NBA 4, 616: „Quae utrum sit Trinitas, non solum credentibus, divinae Scripturae auctoritate; verum etiam intelligentibus, aliqua, si possumus, ratione iam demonstrare debemus", tłum. Stokowska, s. 458.

${ }^{42}$ Por. Gilson, Wprowadzenie, s. 36n.
} 
Mam nadzieję, że powyższe rozważania pokazały jasno, że postawienie wiary przed rozumem nie jest koncepcją pojawiającą się jedynie u autorów chrześcijańskich, którzy przyznali wierze dużo większe znaczenie niż rozumowi. Analizując poglądy Platona mogliśmy zobaczyć, że wiarę można traktować jako naturalnie występujący i konieczny element procesu poznawczego, który jednak zanika w momencie, kiedy człowiek dojdzie do oglądania idei. W przypadku Plotyna podkreślenie elementu wolitywnego sprawiło, że wiara (przekonanie) musiała nieustannie towarzyszyć człowiekowi w jego drodze ku szczęściu zjednoczenia z Jednym. Filozof ów, który miał tak wielki wpływ na św. Augustyna, pokazuje jednak najlepiej kluczowy element, bez którego rozróżnianie wiary i rozumu u obydwu autorów nie może być uczynione poprawnie. Biskupa Hippony, podobnie jak Plotyna, w ogóle nie interesuje czysto teoretyczne rozróżnienie wiary i rozumu. Zawsze chodzi o szukanie Boga, dążenie ku szczęściu, przejście pewnej drogi, którą człowiek podejmuje w swoim życiu. Dlatego właśnie św. Augustyn będzie powtarzał, że intellectio est merces fidei $i^{43}$, ponieważ zawsze chodzi nie o uzyskanie jakiejś wiedzy, która byłaby bardziej lub mniej uprawniona i pewna, ale właśnie o nagrodę wiary. Rozróżnienie to, o ile jest w ogóle w tym aspekcie konieczne, ma sens tylko w dynamice dążenia człowieka ku szczęściu.

Jeżeli więc posługując się współczesnymi, czysto teoretycznymi kategoriami, próbujemy stwierdzić, że św. Augustyn był bardziej teologiem niż filozofem, ponieważ dawał pierwszeństwo wierze, to taki sam zarzut powinniśmy wysunąć wobec Platona i Plotyna. Oni tak samo uznawali, że wiara jest konieczna, ponieważ człowiek zanim wejdzie na drogę musi przyjąć do swego wnętrza przekonanie, że w ogóle warto na nią wejść, a więc musi dostrzec dzięki wierze wewnętrzną prawdziwość słów zachęty wypowiadanych przez nauczyciela.

Nie znaczy to jednak wcale, że u autorów chrześcijańskich nie ma rozróżnienia pomiędzy filozofią i teologią. Ono oczywiście istnieje, ale jest w zupełnie innym miejscu. Jeżeli chcemy go szukać, to nie wystarczy jedynie wskazać na passusy, w których piszą, że wiara ma pierwszeństwo przed rozumem. Należy raczej sięgnąć do tych fragmentów dzieł chrześcijańskich autorów, w których zaczynają oni komentować i rozważać prawdy Pisma Świętego, przyjęte za prawdziwe dzięki wierze nadprzyrodzonej. Rozważanie tych prawd różni się zasadniczo od filozofii właśnie tym, że o ile jesteśmy w stanie dojść do zrozumienia prawd filozoficznych, czy - jakby to powiedział Platon - do oglądania idei, o tyle prawdy Pisma Świętego nieustannie rozważane, ciągle będą pozostawały dla rozumu nieprzeniknione. Dlatego właśnie ich studiowanie musi być wspomagane wiarą w znaczeniu nadprzyrodzonej łaski. Rozum bowiem nie będzie w stanie dostrzec ich wewnętrznej konieczności na tyle,

${ }^{43}$ Por. Augustinus, Sermo 43, 1, 1, ed. A. Trapè, NBA 29, Roma 1979, 750; tenże, Sermo 139, 1, 1, ed. A. Trapè, NBA 31/1, Roma 1990, 320. 
aby wola mogła zapewnić go o sensowności trwania przy nich i dalszego ich rozważania. Dopiero pomoc i światło łaski pozwoli dostrzec zawartą w nich prawdę na tyle, aby umysł nie zniechęcał się ciągłym poznawaniem tego, czego nie jest w stanie przeniknąć.

\author{
FAITH SEEKING UNDERSTANDING \\ IN CONTEXT OF STRIVING TO ACHIEVE HAPPINESS \\ ACCORDING TO PLATO, PLOTINUS AND ST. AUGUSTINE
}

(Summary)

Well known sentence fides quaerens intellectum often mentioned by St. Augustine of Hippo and very popular in medieval theology is often understood in such a way, that act of faith must be prior to rational cognition. Faith is understood in this sentence, as acceptance of Christian Revelation and natural cognition seems to be impossible without prior act of faith. The purpose of this article is to show, that faith or belief ( $\pi i \sigma \tau \imath \zeta)$ is present in the writings of pagan philosophers (especially Plato and Plotinus) as the necessary stage of the process of cognition. It can be seen especially in the context of philosophical life understood as seeking happiness. To enter the path of philosophical life it is necessary for the pupil to listen and believe in the words of the master. Pupil believing in authority of the master must obtain the conviction, that entering the path of the true philosophy is worth the effort and that it is possible to have the higher understanding and knowledge. At the end of the path belief disappears, because pupil can penetrate the higher truth and understand it himself. Analysis of mutual relation of faith and understanding in pagan philos ophers shows that it is not sufficient to point out the priority of faith to classify Christian writers (especially St. Augustine) as theologians rather then philosophers, since this sequence could occur at natural level.

Key words: Plato, Plotinus, St. Augustine, faith, belief, reason.

Słowa kluczowe: Platon, Plotyn, św. Augustyn, wiara, rozum. 